Nig. J. Anim. Prod. 2021, 48(3): 142 - 153. doi.org/10.51791/njap.v48i3.2974

(C) Nigerian Society for Animal Production

Chemical composition of hay produced from three different drying techniques

${ }^{1}$ EEwetola, I. A., ${ }^{3}$ Adebayo, K. O., ${ }^{2}$ Amisu, A. A, ${ }^{4}$ Jimoh, S. O., ${ }^{2}$ Dele, P. A., ${ }^{2}$ Olanite, J. A. and ${ }^{2}$ Arigbede, O. M.

${ }^{1}$ Department of Animal Nutrition and Forage Science,

College of Animal Science and Animal Production,

Michael Okpara University of Agriculture, Umudike, Umuahia, Abia state.

${ }^{2}$ Department of Pasture and Range Management,

College of Animal Science and livestock Production,

Federal University of Agriculture, Abeokuta, Ogun state.

${ }^{3}$ Department of Animal Nutrition, College of Animal Science and livestock Production,

Federal University of Agriculture, Abeokuta, Ogun state.

${ }^{4}$ Grassland Research Institute, Chinese Academy of Agricultural Sciences/Key Laboratory

of Grassland Ecology and Restoration, Ministry of Agriculture,

120 East Wulanchabu Street, Hohhot, Inner Mongolia 010010

Abstract

*Corresponding author: ewetolaibb@gmail.com

Sporadic change in weather condition has posed serious threat to hay production which has been considered to be the simplest means of conserving forage during the period of abundance. In order to maximize opportunity of ensuring that forage is conserved with less weather dependent technique, an experiment was conducted to evaluate chemical composition of hay produced from three different drying techniques stored for a period of 90 days in South-west Nigeria. The experiment comprises three factors namely: Four fertilizer types, two grass species and three drying techniques forming $4 \times 2 \times 3$ factorial arrangement, having 24 total treatments combinations replicated thrice. The fertilizer types were N.P. K. 20:10:10 (NPK), Aleshinloye organo-mineral (AOM) and poultry manure (PM) and a control. These were applied at the rate of $120 \mathrm{kgN} / \mathrm{ha}$ based on their nitrogen content. The grasses were Panicum maximum (Ntchisi) and Andropogon tectorum which were harvested at 8 weeks after cutting back (8WAC) in early dry season period in the year 2016. The three drying techniques were oven drying, solar drying and conventional drying. The results presented shows that solar dried hay were observed to produce the highest significant $(P<0.05)$ crude protein $(C P)(9.50,8.81$ and $8.41 \%)$ at 0,6 and 12 weeks after storage $(W A S)$, respectively. Meanwhile, the highest $(P<0.05)$ ash $(9.77 \%)$ was observed in conventional dried hay at 6 WAS. The highest $(P<0.05)$ ether extract $(E E)(5.92 \%)$ was obtained in conventional dried hay at 12 WAS. The highest $(P<0.05)$ Non Fibre Carbohydrate (NFC) values (23.35, 29.19 and 44.41\%) were observed in conventional dried hay, while the lowest $(P<0.05)$ NFC values $(10.42,25.12$ and $37.55 \%)$ were obtained in solar dried hay at 0, 6 and 12 WAS, respectively. The highest $(P<0.05)$ Neutral Detergent Fibre (NDF) (58.08 and 48.83\%) were observed in oven and solar drying techniques at 0 and 6 WAS respectively. Conventional dried hay had the highest ADL (14.58\%) at 12 WAS. The highest $(P<0.05)$ hemicellulose $(16.17$ and $24.58 \%)$ were recorded in solar dried hay at 0 and 6, WAS respectively. In conclusion, solar drying technique produced best hay having the highest CP content throughout the sampling periods, although the CP content was decreased as the storage progresses, but it still retained the CP content beyond the recommended rate for optimum animal performance.

Keywords: drying, technique, chemical, composition, hay 


\section{Chemical composition of hay produced from three different drying techniques}

\section{La Composition chimique du foin produite à partir de trois techniques de séchage différentes}

\section{Résumé}

Les changements sporadiques dans les conditions météorologiques ont posé une grave menace à la production de foin, qui a été considérée comme le moyen le plus simple de conserver le fourrage pendant la période d'abondance. Afin de maximiser les possibilités de s'assurer que le fourrage est conservé avec une technique moins dépendante des conditions météorologiques, une expérience a été menée pour évaluer la composition chimique du foin produite à partir de trois techniques de séchage différentes stockées pendant une période de 90 jours dans le sud-ouest du Nigéria. L'expérience comprend trois facteurs: quatre types d'engrais, deux espèces d'herbe et trois techniques de séchage formant $4 \times 2 \times 3$ arrangement factorial, ayant 24 combinaisons totales de traitements répliquées trois fois. Les types d'engrais étaient N.P. K. 20:10:10 (le 'NPK'), Aleshinloye organo-minéral (le 'AOM') et fumier de volaille (le 'PM') et un contrôle. Ceux-ci ont été appliqués à un taux de $120 \mathrm{kgN} / \mathrm{ha}$ en fonction de leur teneur en azote. Les graminées étaient panicum maximum (Ntchisi) et Andropogon tectorum qui ont été récoltées à 8 semaines après la coupe (8WAC) au début de la saison sèche en 2016. Les trois techniques de séchage étaient le séchage au four, le séchage solaire et le séchage conventionnel. Les résultats présentés montrent que le foin séché solaire a été observé pour produire la protéine brute $(C P)$ la plus importante $(P<0,05)(C P)(9,50$, 8,81 et 8,41\%) 0, 6 et 12 semaines après le stockage (WAS), respectivement. Pendant ce temps, les cendres les plus $<(P<0,05)(9,77 \%)$ a été observé dans le foin séché conventionnel à 6 WAS. Extrait d'éther $(P<0,05)$ le plus élevé $(E E)(5,92 \%)$ a été obtenu dans le foin séché conventionnel à 12 WAS. Les valeurs les plus élevées $(P<0,05)$ non fibre de carbone $(N F C)$ (23,35, 29,19 et 44,41\%) ont été observées dans le foin séché conventionnel, tandis que les valeurs NFC les plus faibles $(P<0,05)(10,42,25,12$ et 37,55\%) ont été obtenus dans le foin séché solaire à 0 , 6 et $12 \mathrm{WAS}$, respectivement. Fibre détergente neutre (NDF) la plus élevée $(P<0,05)(N D F)(58,08$ et 48,83\%) ont été observés dans les techniques de séchage au four et solaire à 0 et 6 WAS respectivement. Le foin séché conventionnel avait l'ADL le plus élevé (14.58\%) à 12 WAS. L'hémicellulose la plus élevée $(P<0,05)(16,17$ et 24,58\%) ont été enregistrés dans le foin séché solaire à 0 et 6 , WAS respectivement. En conclusion, la technique de séchage solaire a produit le meilleur foin ayant la teneur en CP la plus élevée tout au long des périodes d'échantillonnage, bien que la teneur en CP ait diminué au fur et à mesure que l'entreposage progresse, mais elle a tout de même conservé la teneur en CP audelà du taux recommandé pour une performance optimale des animaux.

Mots-clés: séchage, technique, produit chimique, composition, foin

\section{Introduction}

Ruminants have abundance of forage to feed on in the rainy season, and as such, animals are well fed and fattened due to availability of highly nutritive forage materials. Consequently, in the dry season, they usually experience significant loss of weight and remarkable decline in milk production as a result of low quality feed resources (Lamidi and Ologbose, 2014).
Meanwhile, agro-industrial by-products have been adopted as alternative feed resource for ruminants feeding during dry season (Andrew et al., 2014; Mamine et al., 2020). These materials are known to have poor nutritive quality and low digestibility unless they are further processed before presenting to animals which will, in turn, increase the cost of production of animals. Intake of these agro-industrial by-products 


\section{Ewetola, Adebayo, Amisu, Jimoh, Dele, Olanite and Arigbede}

in the raw state by ruminants is usually too low to maintain body weight due to their tough texture, poor digestibility and low nutrient content (Kaitho, 1997; Sindhu, 2002). In view of the demerits of crop residues and industrial wastes materials as dry season feed resource for ruminants, therefore, conservation of forage still remains the best approach to ensure year round production. Due to abundance of high quality of forages during rainy season, hay and silage making have been recommended, on the premise that farmers can use these conservation techniques onfarm provided they have sufficient man power and can obtain forage during the late wet season from any available pasture field (Ewetola, 2018).

A major constraint to adoption of haymaking as preferred possible solution to ameliorate the problem of forage scarcity during dry season for efficient drying process, more energy is needed from solar radiation and convection towards the end of the field-drying period to remove water from within flowering stem tissue than water from leaves and the outer layers of the stem that is lost rapidly in the initial phase of the field-drying process. Consequently, the rate at which the crop dries decreases as drying proceeds (Wilkinson, 2016). Thus, the vulnerability of haymaking to loss of nutrients due to poor weather has been a serious setback to utilization of hay as dry season feed (Wilkinson, 2016). Nascimento et al. (2000) found that there was a decrease in hay quality when they remained under the sun, especially crude protein, neutral detergent fibre, and acid detergent fibre. Moreover, further nutrients losses occur during storage due to spontaneous heating. Heating during hay storage oxidizes sugars, thereby resulting in greater concentrations of fibre components and reduced estimates of energy density (Coblentz, 2010). Similarly, Guerrero (2006) reported that as hay storage time increases, the hay loses
Dry Matter (DM), and increases in Neutral Detergent Fibre (NDF) and Acid Detergent Fibre (ADF). Therefore, this study was conducted to evaluate chemical composition of hay produced from three different drying techniques stored for a period of 90 days in south west Nigeria.

\section{Materials and methods Experimental design}

The experiment comprises three factors namely: Four fertilizer types, two grass species and three drying techniques forming $4 \times 2 \times 3$ factorial arrangement laid out in a randomized complete block design having 24 total treatments combinations replicated thrice. The fertilizer types were N.P. K. 20:10:10 (NPK), Aleshinloye organo-mineral (AOM) and poultry manure (PM) and a control. These were applied at the rate of $120 \mathrm{kgN} / \mathrm{ha}$ based on their nitrogen content. The grasses were Panicum maximum (Ntchisi) and Andropogon tectorum which were harvested at 8 weeks after cutting back (8WAC). The three drying techniques were oven drying, solar drying (i.e. transparent roofing structure covered with black Tarpaulin) and conventional drying (i.e. open floor drying method i.e. control treatment).

\section{Hayproduction}

Forage samples were harvested on $19^{\text {th }}$ of November, 2016, two $1 \mathrm{~m}^{2}$ quadrat in each plot were used to make hay. Hay was cured by the following drying techniques:

\section{Oven drying technique}

An oven drier built with concrete wall and covered with roofing steel was used. Extra heat was generated by burning firewood in the burning chamber outside the oven room for the period of drying at 2-days interval. The harvested forage samples were placed on plywood materials raised $10 \mathrm{~cm}$ above the concrete floor of the oven room. The plywood was divided into three lines. Each line was demarcated with strong wood 


\section{Chemical composition of hay produced from three different drying techniques}

material to create a barrier for replicate designation. Drying of the chopped (4-5 cm size) forage materials commenced until they became properly dried due to continuous supply of heat and air movement through the spaces created at the upper part of the heating chamber (i.e., oven room). The average temperature of the oven room was $48.4^{\circ} \mathrm{C}$, recorded with the aid of a digital thermometer. When the forage materials had dried to the desired moisture level for two weeks, the dried samples (i.e. hays) were packed inside a white door net that allows free air movement and stored in a cool dry condition for the period of three months.

\section{Solar drying technique}

A structure was constructed with wooden material on a concrete floor at about $120 \mathrm{~cm}$ above the ground level and this was covered with white transparent pan as a roofing material that can allow penetration of sunlight. In addition, the structure was divided into 3 layers which serve as replicate and big black tarpaulin was used to protect the structure in order to prevent absorbed heat from escaping (heat conservation technique). The absorbed heat inside the structure was used to dry the chopped $(5 \mathrm{~cm}$ size) harvested forage samples packed inside the layers with the aid of air movement within the structure until they were properly dried to less than $20 \%$ moisture content for the period of two weeks. Furthermore, during this period, an average temperature of the solar structure was taken and recorded as $32.56^{\circ} \mathrm{C}$ with the aid of a digital thermometer. The dried samples i.e. hays were packed inside white net that allow free air movement during storage and stored in a cool dry condition for the period of three months.

\section{Conventional drying technique}

The harvested forage materials were chopped to $4-5 \mathrm{~cm}$ size, after which they were spread on an open floor and allowed to sundry for the period of two weeks. During this period of drying, the samples were packed inside the net to reduce losses due to wind disturbance and kept in a room every night to prevent moisture re-absorption as result of increase in relative humidity at night and brought out in the following morning when the sun has risen to the level that its impact can be felt. Also, slight turning of the samples was done to ensure uniform drying. Thereafter, the hay was packed inside white net that allow free air movement and stored in a cool dry condition for the period of three months.

\section{Storage of hay}

This commenced on 1st of December, 2016 after the samples placed in different drying conditions have dried for a period of two weeks and the hays packed inside white net were stored in a cool dry condition. The hays were sampled at intervals of six weeks during storage period of three months $(0,6$ and 12 weeks). The sub-samples taken were used for determination of chemical composition during this period.

\section{Determination of proximate composition}

The contents of dry matter (DM \%), crude protein $(\mathrm{CP})$, ether extract $(\mathrm{EE})$ and ash were determined according to A.O.A.C. (2000). Non-fibre carbohydrates (NFC) was calculated as $\mathrm{NFC}=100-$ $(\mathrm{CP}+\mathrm{ash}+\mathrm{EE}+\mathrm{NDF})$.

\section{Determination of fibre fractions}

Neutral detergent fibre (NDF), acid detergent fibre (ADF) and acid detergent lignin (ADL) were determined Van Soest et al. (1991) while cellulose was calculated subtracted the ADL values from ADF values and hemicellulose as the difference between NDF values and ADF values.

\section{Experimental model}

$\mathrm{Y}_{\mathrm{ijkl}}=\mu+\mathrm{F}_{\mathrm{i}}+\mathrm{G}_{\mathrm{j}}+\mathrm{D}_{\mathrm{k}}+(\mathrm{FG})_{\mathrm{ij}}+(\mathrm{FD})_{\mathrm{ik}}+(\mathrm{GD})_{\mathrm{jk}}$ $+(\text { FGD })_{\mathrm{ijk}} \sum_{\mathrm{ijkl}}$

$\mu=$ population mean

$\mathrm{F}_{\mathrm{i}=}$ effect of fertilizer types

$\mathrm{G}_{\mathrm{j}=}$ effect of grass species

$\mathrm{D}_{\mathrm{k}=}$ effect of drying techniques

$(\mathrm{FG})_{\mathrm{ij}}=$ interaction of fertilizer types and 


\section{Ewetola, Adebayo, Amisu, Jimoh, Dele, Olanite and Arigbede}

grass species effects

(FD) ${ }_{\mathrm{ik}}=$ interaction of fertilizer types and drying techniques effects

$(G D)_{j \mathrm{k}}=$ interaction of grass species and drying techniques effects

$(\mathrm{FGH})_{\mathrm{ijk}}=$ interaction of fertilizer types, grass species and drying techniques effects

$\sum_{\mathrm{ijkl}=}$ Residual error estimate

\section{Results}

Main effects of grass species, fertilizer type, and drying technique on crude protein and ash content of differently sampled dried hay at six-weeks interval during the storage period

The mean values of $\mathrm{CP}$ and ash were $(\mathrm{P}<0.05)$ different. Generally, the results indicate that $\mathrm{CP}$ and ash gradually decrease as the storage period advanced. The higher CP $(8.28 \%)$ was observed in AOM at 0 weeks, and PM at 6 and 12 WAS (7.42 and $7.69 \%$ respectively. Solar dried hay produced the higher CP $(9.50,8.81$ and $8.41 \%$ ) at 0,6 and 12 WAS. However, the higher ash (9.77 \%) was recorded in conventional dried hay at 6 WAS.

Main effects of grass species, fertilizer type, and drying technique on ether extract and non-fibre carbohydrate of differently sampled dried hay at intervals of six weeks during storage period

The main effect of grass species, fertilizer type and drying technique on ether extract (EE \%) and non-fibre carbohydrate (NFC $\%$ ) of differently sampled dried hay at an interval of six weeks during storage period are presented in Table 2. The mean values show that EE was decreasing while NFC was increasing as storage period progressed. The higher EE $(5.92 \%)$ was obtained in conventional dried hay at 12 weeks. The higher NFC values (23.35, 29.19 and $44.41 \%$ ) were observed in conventional dried hay, while the lower NFC values (10.42, 25.12 and $37.55 \%$ ) were obtained in solar dried hay at 0, 6 and 12 weeks, respectively
Interaction effect of grass species, fertilizer type, and drying technique on crude protein and ash content of differently sampled and dried hay at sixweeks interval during the storage period

Table 3 expresses the interaction effects of fertilizer type, drying techniques on crude protein and Ash content of hay produced from two grasses sampling at an interval of six weeks. There were no significant differences $(\mathrm{P}>0.05)$ among the mean values of ash at 12 weeks after storage (WAS). At 0 week, the higher CP (10.59\%) was observed in solar dried hay produced from A. tectorum fertilized with AOM, while the lowest CP $(5.08 \%)$ was in conventional dried hay produced from $P$. maximum under control treatment. Samplings during the storage, indicates that the higher CP (10.10 and 9.70\%) were observed in solar dried hay produced from A. tectorum fertilized with PM at 6 and 12 WAS respectively, while the lower CP (4.95 and $4.73 \%$ ) were observed in conventional dried hay produced from $A$. tectorum under control treatment (no fertilizer) at 6 and 12 WAS, respectively. The higher ash $(15.67 \%)$ was observed in oven dried hay produced from $A$. tectorum fertilized with PM and lower ash (6.10\%) was in conventional dried hay produced from $P$. maximum (Ntchisi) fertilized with AOM at 0 week. However, at 6 weeks, the higher ash $(12.47 \%)$ was observed in conventional dried hay produced from $A$. tectorum fertilized with AOM and the lower ash $(4.33 \%)$ was obtained in solar dried hay produced from $A$. tectorum fertilized with NPK.

Interaction effect of grass species, fertilizer type, and drying technique on ether extract (EE) and non-fibre carbohydrate (NFC) content of differently sampled and dried hay at six-weeks interval during the storage period

There were no differences ( $\mathrm{P}>0.05)$ among the mean values except NFC at 0 week 


\section{Chemical composition of hay produced from three different drying techniques}

Table 1: Main effects of grass species, fertilizer type, and drying technique on crude protein and ash content of differently sampled dried hay at six-weeks interval during the storage period

\begin{tabular}{lllllll}
\hline Factors & $\mathrm{CP}(\%)$ & \multicolumn{5}{c}{ Ash $(\%)$} \\
\cline { 2 - 7 } & 0 week & 6 weeks & 12 weeks & 0 week & 6 weeks & 12 weeks \\
\hline Grass species & & & & & & \\
A. tectorum & 7.85 & 7.16 & 7.05 & 10.71 & 9.32 & 9.43 \\
P. maximum & 7.55 & 6.83 & 6.60 & 9.72 & 9.34 & 9.49 \\
SEM & 0.31 & 0.30 & 0.30 & 0.41 & 0.24 & 0.26 \\
Fertilizer type & & & & & & \\
Control & $6.94^{\mathrm{b}}$ & $6.30^{\mathrm{b}}$ & $6.06^{\mathrm{b}}$ & 10.21 & 9.60 & 9.52 \\
AOM & $8.23^{\mathrm{a}}$ & $7.33^{\mathrm{a}}$ & $6.89^{\mathrm{ab}}$ & 9.43 & 9.86 & 9.86 \\
NPK & $7.73^{\mathrm{ab}}$ & $6.94^{\mathrm{ab}}$ & $6.65^{\mathrm{ab}}$ & 9.76 & 8.78 & 9.68 \\
PM & $7.89^{\mathrm{ab}}$ & $7.42^{\mathrm{a}}$ & $7.69^{\mathrm{a}}$ & 11.46 & 9.07 & 8.77 \\
SEM & 0.43 & 0.41 & 0.40 & 0.56 & 0.32 & 0.34 \\
Drying technique & & & & & & \\
Conventional & $6.26^{\mathrm{c}}$ & $5.30^{\mathrm{c}}$ & $5.16^{\mathrm{c}}$ & 8.93 & $9.77^{\mathrm{a}}$ & 9.68 \\
Oven & $7.34^{\mathrm{b}}$ & $6.80^{\mathrm{b}}$ & $6.89^{\mathrm{b}}$ & 10.78 & $9.55^{\mathrm{ab}}$ & 9.41 \\
Solar & $9.50^{\mathrm{a}}$ & $8.81^{\mathrm{a}}$ & $8.41^{\mathrm{a}}$ & 10.92 & $8.66^{\mathrm{b}}$ & 9.29 \\
SEM & 0.27 & 0.20 & 0.23 & 0.47 & 0.27 & 0.31 \\
\hline
\end{tabular}

a, b, c: means in the same column with different superscripts are significantly different $(\mathrm{P}<0.05)$

$\mathrm{SEM}=$ Standard error of the mean,

$\mathrm{AOM}=$ Aleshinloye organo-mineral fertilizer

PM=Poultry manure; NPK=N.P.K. 20:10:10

Table 2: Main effects of grass species, fertilizer type, and drying technique on ether extract and nonfibre carbohydrate of differently sampled dried hay at intervals of six weeks during storage period

\begin{tabular}{|c|c|c|c|c|c|c|}
\hline \multirow[t]{2}{*}{ Factors } & \multicolumn{3}{|l|}{$\mathrm{EE}(\%)$} & \multicolumn{3}{|c|}{ NFC $(\%)$} \\
\hline & 0 week & 6 weeks & 12 weeks & 0 week & 6 weeks & 12 weeks \\
\hline \multicolumn{7}{|l|}{ Grass species } \\
\hline A. tectorum & 11.03 & 9.11 & 4.69 & 14.63 & 26.97 & 40.50 \\
\hline P. maximum & 11.36 & 9.85 & 5.03 & 16.20 & 27.04 & 41.27 \\
\hline SEM & 0.36 & 0.50 & 0.33 & 0.53 & 0.41 & 0.36 \\
\hline \multicolumn{7}{|l|}{ Fertilizer type } \\
\hline Control & 11.78 & 9.22 & 5.11 & 14.29 & 29.05 & 41.25 \\
\hline $\mathrm{AOM}$ & 11.72 & 9.28 & 4.78 & 16.29 & 25.70 & 40.36 \\
\hline NPK & 10.56 & 10.31 & 5.00 & 16.39 & 26.53 & 40.56 \\
\hline PM & 10.72 & 9.17 & 4.56 & 14.71 & 26.67 & 41.37 \\
\hline SEM & 0.50 & 0.72 & 0.47 & 0.73 & 0.56 & 0.50 \\
\hline \multicolumn{7}{|c|}{ Drying technique } \\
\hline Conventional & 10.96 & 9.74 & $3.96^{\mathrm{b}}$ & $23.35^{\mathrm{a}}$ & $29.19^{\mathrm{a}}$ & $44.41^{\mathrm{a}}$ \\
\hline Oven & 11.29 & 10.13 & $4.71^{\mathrm{ab}}$ & $12.51^{\mathrm{b}}$ & $26.77^{\mathrm{ab}}$ & $40.70^{\mathrm{b}}$ \\
\hline Solar & 11.33 & 8.58 & $5.92^{\mathrm{a}}$ & $10.42^{\mathrm{c}}$ & $25.12^{\mathrm{b}}$ & $37.55^{\mathrm{c}}$ \\
\hline SEM & 0.45 & 0.61 & 0.38 & 0.56 & 0.44 & 0.40 \\
\hline
\end{tabular}




\section{Ewetola, Adebayo, Amisu, Jimoh, Dele, Olanite and Arigbede}

(Table 4). The higher NFC (29.20\%) was observed in conventional dried hay produced from $A$. tectorum under control treatment at 0 weeks, while the lower $(5.46 \%)$ was observed in oven-dried hay produced from $A$. tectorum fertilized with
PM. At 12 weeks, NFC was higher in conventional dried hay produced from $A$. tectorum under control treatment $(46.11 \%)$, while the lower value $(34.15 \%)$ was obtained in oven-dried hay produced from A. tectorum under control treatment.

Table 3: Interaction effect of grass species, fertilizer type, and drying techniqu es on crude protein and ash content of differently sampled and dried hay at six weeks interval during the storage period

\begin{tabular}{|c|c|c|c|c|c|c|c|c|}
\hline \multirow[t]{2}{*}{ Treatments } & & & \multicolumn{3}{|l|}{ CP $(\%)$} & \multicolumn{3}{|l|}{ Ash (\%) } \\
\hline & & & 0week & 6weeks & 12weeks & 0week & 6weeks & 12 weeks \\
\hline $\begin{array}{l}\text { Drying } \\
\text { technique }\end{array}$ & $\begin{array}{l}\text { Fertilize } \\
\text { r type }\end{array}$ & $\begin{array}{c}\text { Grass } \\
\text { species }\end{array}$ & & & & & & \\
\hline \multirow[t]{8}{*}{ Conventional } & AOM & A. tectorum & $6.63^{\mathrm{c}-\mathrm{f}}$ & $5.87^{\text {ggh }}$ & $5.56^{\mathrm{c}-\mathrm{f}}$ & $9.63^{\mathrm{abc}}$ & $12.47^{\mathrm{a}}$ & 9.37 \\
\hline & & P. maximum & $7.53^{\mathrm{a}-\mathrm{f}}$ & $5.28^{\mathrm{h}}$ & $5.19^{\text {def }}$ & $6.10^{\mathrm{c}}$ & $9.20^{\mathrm{bc}}$ & 9.80 \\
\hline & NPK & A. tectorum & $7.36^{\mathrm{b}-\mathrm{f}}$ & $5.28^{\mathrm{h}}$ & $5.25^{\mathrm{def}}$ & $9.40^{\mathrm{abc}}$ & $8.93^{\mathrm{bc}}$ & 9.80 \\
\hline & & P. maximum & $5.93^{\text {def }}$ & $5.10^{\mathrm{h}}$ & $5.07^{\mathrm{ef}}$ & $6.60^{\mathrm{bc}}$ & $9.47^{\mathrm{bc}}$ & 9.77 \\
\hline & PM & A. tectorum & $5.50^{\text {ef }}$ & $5.19^{\mathrm{h}}$ & $5.19^{\mathrm{def}}$ & $9.97^{\mathrm{abc}}$ & $9.40^{\mathrm{bc}}$ & 8.93 \\
\hline & & P. maximum & $6.63^{\mathrm{c}-\mathrm{f}}$ & $5.84^{\text {fgh }}$ & $5.33^{\mathrm{c}-\mathrm{f}}$ & $10.27^{\mathrm{abc}}$ & $9.20^{b c}$ & 9.70 \\
\hline & Control & A. tectorum & $5.42^{\mathrm{ef}}$ & $4.95^{\mathrm{h}}$ & $4.73^{\mathrm{f}}$ & $7.63^{b c}$ & $9.83^{\mathrm{abc}}$ & 10.90 \\
\hline & & P. maximum & $5.08^{\mathrm{f}}$ & $4.96^{\mathrm{h}}$ & $4.95^{\mathrm{ef}}$ & $11.87^{\mathrm{abc}}$ & $9.67^{\mathrm{bc}}$ & 9.17 \\
\hline \multirow[t]{8}{*}{ Oven } & $\mathrm{AOM}$ & A. tectorum & $8.58^{\mathrm{a}-\mathrm{e}}$ & $8.19^{\mathrm{bcd}}$ & $7.70^{\mathrm{a}-\mathrm{e}}$ & $10.80^{\mathrm{abc}}$ & $10.00^{\mathrm{abc}}$ & 10.17 \\
\hline & & P. maximum & $6.77^{\mathrm{c}-\mathrm{f}}$ & $5.99^{\mathrm{fgh}}$ & $5.66^{\mathrm{c}-\mathrm{f}}$ & $9.40^{\mathrm{abc}}$ & $8.37^{\mathrm{bc}}$ & 8.90 \\
\hline & NPK & A. tectorum & $6.03^{\operatorname{def}}$ & $5.60^{\mathrm{gh}}$ & $5.32^{\mathrm{c}-\mathrm{f}}$ & $10.47^{\mathrm{abc}}$ & $10.20^{\mathrm{ab}}$ & 10.23 \\
\hline & & P. maximum & $6.69^{c-f}$ & $6.40^{\text {efgh }}$ & $6.30^{b-f}$ & $9.83^{\mathrm{abc}}$ & $9.43^{\mathrm{bc}}$ & 9.27 \\
\hline & PM & A. tectorum & $6.53^{\mathrm{c}-\mathrm{f}}$ & $6.37^{\text {fgh }}$ & $9.05^{\mathrm{ab}}$ & $15.67^{\mathrm{a}}$ & $9.67^{\mathrm{bc}}$ & 9.57 \\
\hline & & P. maximum & $9.11^{\mathrm{a}-\mathrm{d}}$ & $8.21^{\text {bcd }}$ & $7.99^{a-d}$ & $9.67^{\mathrm{abc}}$ & $9.57^{\mathrm{bc}}$ & 8.33 \\
\hline & Control & A. tectorum & $8.37^{\mathrm{a}-\mathrm{e}}$ & $7.73^{\text {bcde }}$ & $7.51^{\mathrm{a}-\mathrm{f}}$ & $10.30^{\mathrm{abc}}$ & $9.40^{\mathrm{bc}}$ & 9.67 \\
\hline & & P. maximum & $6.59^{\mathrm{c}-\mathrm{f}}$ & $5.70^{\mathrm{gh}}$ & $5.59^{\mathrm{c}-\mathrm{f}}$ & $10.13^{\mathrm{abc}}$ & $9.77^{\mathrm{bc}}$ & 9.13 \\
\hline \multirow[t]{8}{*}{ Solar } & $\mathrm{AOM}$ & A. tectorum & $10.59^{\mathrm{a}}$ & $10.06^{\mathrm{a}}$ & $9.03^{\mathrm{ab}}$ & $9.73^{\mathrm{abc}}$ & $9.17^{\mathrm{bc}}$ & 9.57 \\
\hline & & P. maximum & $9.30^{a b c}$ & $8.61^{\mathrm{abcd}}$ & $8.17^{\mathrm{abc}}$ & $10.90^{\mathrm{abc}}$ & $9.97^{\mathrm{abc}}$ & 8.33 \\
\hline & NPK & A. tectorum & $10.23^{\mathrm{ab}}$ & $9.13^{\mathrm{abc}}$ & $8.86^{\mathrm{ab}}$ & $10.80^{\mathrm{abc}}$ & $4.33^{\mathrm{d}}$ & 9.37 \\
\hline & & P. maximum & $10.16^{\mathrm{ab}}$ & $9.34^{\mathrm{ab}}$ & $9.11^{\mathrm{ab}}$ & $11.43^{\mathrm{abc}}$ & $10.30^{\mathrm{ab}}$ & 9.67 \\
\hline & PM & A. tectorum & $10.48^{\mathrm{ab}}$ & $10.10^{\mathrm{a}}$ & $9.70^{\mathrm{a}}$ & $12.60^{\mathrm{ab}}$ & $9.20^{\mathrm{bc}}$ & 7.57 \\
\hline & & P. maximum & $9.08^{a-d}$ & $8.79^{\mathrm{abc}}$ & $8.86^{\mathrm{ab}}$ & $10.60^{\mathrm{abc}}$ & $7.40^{\mathrm{c}}$ & 8.53 \\
\hline & Control & A. tectorum & $8.45^{\mathrm{a-e}}$ & $7.45^{\mathrm{cdef}}$ & $6.65^{b-f}$ & $11.50^{\mathrm{abc}}$ & $9.20^{\mathrm{bc}}$ & 8.63 \\
\hline & & P. maximum & $7.70^{\mathrm{a}-\mathrm{f}}$ & $6.99^{\operatorname{defg}}$ & $6.92^{\mathrm{a}-\mathrm{f}}$ & $9.80^{\mathrm{abc}}$ & $9.73^{\mathrm{bc}}$ & 9.63 \\
\hline SEM & & & 0.49 & 0.26 & 0.34 & 0.78 & 0.29 & 0.48 \\
\hline
\end{tabular}




\section{Chemical composition of hay produced from three different drying techniques}

Main effects of grass species, fertilizer type, and drying techniques on fibre fraction of differently dried hay at sixweeks interval during the storage period

The mean values of ADL at 0 and 12 weeks were significantly affected by grass species and fertilizer types (Table 5). The highest ADL $(14.42 \%)$ was observed in A. tectorum at 12 weeks. The grasses fertilized with NPK had the highest ADL (12.83\%) at 0 week, while the lowest ADL value $(9.00 \%)$ was observed in the grasses fertilized with
AOM. More so, the values presented indicate that NDF was decreasing and hemicelluloses did not show a particular trend as the storage period advanced. The highest NDF (58.08 and 48.83\%) was observed in the oven and solar drying techniques at 0 and 6 weeks, respectively. Conventional dried hay had the highest ADL (14.58\%) at 12 weeks. The highest hemicellulose (16.17 and 24.58\%) was observed in solar dried hay at 0 and 6 weeks, respectively.

Table 4: Interaction effect of grass species, fertilizer type, and drying technique on ether extract

(EE) and non -fibre carbohydrate (NFC) content of differently sampled and dried hay at six weeks interval during the storage period

\begin{tabular}{|c|c|c|c|c|c|c|c|c|}
\hline \multirow[t]{2}{*}{ Treatments } & & & \multicolumn{3}{|l|}{$\mathrm{EE}(\%)$} & \multicolumn{3}{|c|}{ NFC (\%) } \\
\hline & & & 0week & 6weks & 12weks & 0week & 6weks & 12weks \\
\hline $\begin{array}{l}\text { Drying } \\
\text { technique }\end{array}$ & $\begin{array}{l}\text { Fertilizer } \\
\text { type }\end{array}$ & Grass species & & & & & & \\
\hline \multirow[t]{8}{*}{ Conventional } & $\mathrm{AOM}$ & A. tectorum & 11.33 & 10.00 & 4.67 & $22.74^{b}$ & 26.99 & $42.07^{\mathrm{c}}$ \\
\hline & & P. maximum & 10.00 & 10.67 & 3.33 & $26.04^{\mathrm{ab}}$ & 26.18 & $44.68^{b}$ \\
\hline & NPK & A. tectorum & 10.33 & 9.67 & 3.00 & $25.24^{\mathrm{ab}}$ & 30.12 & $45.28^{\mathrm{ab}}$ \\
\hline & & P. maximum & 10.00 & 10.33 & 5.00 & $22.47^{\mathrm{bc}}$ & 29.10 & $43.83^{b c}$ \\
\hline & PM & A. tectorum & 9.67 & 9.33 & 2.67 & $25.19^{\mathrm{ab}}$ & 28.08 & $45.21^{\mathrm{ab}}$ \\
\hline & & P. maximum & 11.00 & 12.00 & 3.00 & $20.43^{c}$ & 27.63 & $44.30^{b}$ \\
\hline & Control & A. tectorum & 10.67 & 9.33 & 4.00 & $29.28^{\mathrm{a}}$ & 30.89 & $46.37^{\mathrm{a}}$ \\
\hline & & P. maximum & 14.67 & 7.33 & 6.00 & $15.38^{\mathrm{d}}$ & 33.71 & $43.55^{\mathrm{bc}}$ \\
\hline \multirow[t]{8}{*}{ Oven } & $\mathrm{AOM}$ & A. tectorum & 12.00 & 9.67 & 4.67 & $12.29^{\mathrm{f}}$ & 29.81 & $40.13^{\mathrm{de}}$ \\
\hline & & P. maximum & 11.67 & 9.33 & 3.33 & $14.49^{\text {de }}$ & 25.64 & $46.11^{\mathrm{a}}$ \\
\hline & NPK & A. tectorum & 11.33 & 8.33 & 4.33 & $14.50^{\text {de }}$ & 27.20 & $40.12^{\text {de }}$ \\
\hline & & P. maximum & 10.67 & 16.33 & 5.00 & $15.14^{\mathrm{d}}$ & 21.51 & $42.43^{c}$ \\
\hline & PM & A. tectorum & 12.67 & 8.67 & 5.00 & $5.46^{\mathrm{i}}$ & 27.29 & $38.05^{\mathrm{e}}$ \\
\hline & & P. maximum & 11.00 & 9.00 & 4.67 & $12.55^{\mathrm{f}}$ & 26.89 & $41.01^{\mathrm{de}}$ \\
\hline & Control & A. tectorum & 10.67 & 9.67 & 5.67 & $8.33^{\mathrm{g}}$ & 25.87 & $34.15^{\mathrm{i}}$ \\
\hline & & P. maximum & 10.33 & 9.33 & 5.00 & $17.28^{\mathrm{cd}}$ & 30.87 & $43.61^{b c}$ \\
\hline \multirow[t]{8}{*}{ Solar } & $\mathrm{AOM}$ & A. tectorum & 12.33 & 8.00 & 7.00 & $8.35^{\mathrm{g}}$ & 20.10 & $36.73^{\mathrm{g}}$ \\
\hline & & P. maximum & 13.00 & 8.00 & 5.67 & $13.80^{\mathrm{ef}}$ & 25.42 & $35.50^{\mathrm{h}}$ \\
\hline & NPK & A. tectorum & 10.33 & 8.00 & 5.67 & $6.97^{\mathrm{hi}}$ & 29.54 & $36.10^{\mathrm{gh}}$ \\
\hline & & P. maximum & 10.67 & 9.00 & 7.00 & $14.07^{\mathrm{e}}$ & 22.69 & $35.55^{\mathrm{h}}$ \\
\hline & PM & A. tectorum & 9.33 & 8.67 & 6.67 & $9.26^{\mathrm{fg}}$ & 23.03 & $38.73^{\mathrm{e}}$ \\
\hline & & P. maximum & 10.67 & 7.33 & 5.33 & $15.32^{\mathrm{d}}$ & 27.15 & $40.95^{\mathrm{d}}$ \\
\hline & Control & A. tectorum & 11.67 & 10.00 & 3.00 & $8.05^{\mathrm{gh}}$ & 24.68 & $42.39^{c}$ \\
\hline & & P. maximum & 12.67 & 9.67 & 7.00 & $7.50^{\mathrm{h}}$ & 28.28 & $37.45^{\mathrm{f}}$ \\
\hline SEM & & & 1.10 & 1.25 & 0.90 & 1.24 & 0.84 & 0.83 \\
\hline
\end{tabular}




\section{Ewetola, Adebayo, Amisu, Jimoh, Dele, Olanite and Arigbede}

Table 5: Main effects of grass species and fertilizer type, and drying technique on fibre fractions

(\%) of differently sampled and dfied hay at six weeks interval during the storage period

\begin{tabular}{|c|c|c|c|c|c|c|c|c|c|}
\hline \multirow[t]{2}{*}{ Factors } & \multicolumn{3}{|c|}{ NDF (\%) } & \multicolumn{3}{|c|}{ ADL (\%) } & \multicolumn{3}{|c|}{ Hemicellulose (\%) } \\
\hline & 0 wek & 6 weks & 12 weks & 0 week & 6 weks & 12 weks & 0 wek & 6 weks & 12 weks \\
\hline \multicolumn{10}{|l|}{ Grass species } \\
\hline A. tectorum & 55.78 & 47.44 & 38.33 & 11.03 & 12.53 & $14.42^{\mathrm{a}}$ & 21.61 & 14.61 & 22.39 \\
\hline P. maximum & 55.17 & 46.94 & 37.61 & 11.08 & 12.47 & $13.36^{\mathrm{b}}$ & 23.00 & 13.36 & 22.06 \\
\hline SEM & 1.03 & 0.59 & 0.55 & 0.71 & 0.62 & 0.33 & 0.97 & 0.73 & 0.30 \\
\hline \multicolumn{10}{|l|}{$\begin{array}{l}\text { Fertilizer } \\
\text { type }\end{array}$} \\
\hline Control & 56.78 & 45.83 & 38.06 & $11.83^{\mathrm{ab}}$ & 13.22 & 14.11 & 23.67 & 12.78 & 22.00 \\
\hline $\mathrm{AOM}$ & 54.33 & 47.83 & 38.11 & $9.00^{\mathrm{b}}$ & 10.89 & 13.83 & 22.22 & 14.06 & 21.83 \\
\hline NPK & 55.56 & 47.44 & 38.11 & $12.83^{\mathrm{a}}$ & 13.89 & 13.61 & 22.11 & 14.28 & 22.28 \\
\hline PM & 55.22 & 47.67 & 37.61 & $10.56^{\mathrm{ab}}$ & 12.00 & 14.00 & 21.22 & 14.83 & 22.78 \\
\hline SEM & 1.44 & 0.78 & 0.79 & 0.96 & 0.83 & 0.48 & 1.37 & 1.03 & 0.41 \\
\hline \multicolumn{10}{|l|}{$\begin{array}{l}\text { Drying } \\
\text { technique }\end{array}$} \\
\hline Conventional & $50.50^{\mathrm{b}}$ & $46.00^{\mathrm{b}}$ & 36.79 & 10.92 & 12.42 & $14.58^{\mathrm{a}}$ & $17.83^{b}$ & $12.29^{\mathrm{b}}$ & 22.79 \\
\hline Oven & $58.08^{\mathrm{a}}$ & $46.75^{\mathrm{ab}}$ & 38.29 & 11.50 & 13.08 & $14.04^{\mathrm{ab}}$ & $24.50^{\mathrm{a}}$ & $13.50^{\mathrm{ab}}$ & 21.83 \\
\hline Solar & $57.83^{\mathrm{ab}}$ & $48.83^{\mathrm{a}}$ & 38.83 & 10.75 & 12.00 & $13.04^{b}$ & $24.58^{\mathrm{a}}$ & $16.17^{\mathrm{a}}$ & 22.04 \\
\hline SEM & 1.03 & 0.66 & 0.67 & 0.87 & 0.75 & 0.39 & 1.02 & 0.84 & 0.35 \\
\hline
\end{tabular}

\section{Discussion}

The crude protein content of the hay decreased gradually during the storage period, but still retained the $\mathrm{CP}$ value $(9.50$, 8.81 and $8.41 \%$ ) at the level above the recommended $\mathrm{CP}$ value for optimum animal performance. The higher $\mathrm{CP}$ was observed in the hay produced by solar drying throughout the sampling period. This suggests that the dry matter loss in terms of CP was low in the solar dried hay. This is an indication that nutritive loss during drying was kept low in the solar drying method due to gradual penetration of sunlight rays and ventilation which was achieved through the use of transparent roofing material in the solar structure (Resch et al., 2014). The observation in the present study was in agreement with Nascimento et al. (2000) that there was a decrease in hay quality especially $\mathrm{CP}$, when left under the sun. The decreased $\mathrm{CP}$ values observed in the present study from 6 to 12 weeks after storage for all the three drying techniques suggests that the microbes present in the hay continue to utilize protein content of the hay. This could be attributed to the high production of peptidase that enables the microorganisms to utilize protein available in the stored hay. This might be further related to the fast growth of the microbes from 0 to 6 weeks during storage for utilization of essential proteins. Another reason that could be adduced for this observation might be occurrence of side reaction for protein synthesis, therefore reducing the amount of crude protein that is bio available for the organisms. The highest ash content was recorded in the solar dried hay. This slightly reduced when the storage 


\section{Chemical composition of hay produced from three different drying techniques}

period advanced and beyond 6 weeks during storage ash content increased. The decline in the ash content at the first 6 weeks during storage is an indication that the microbes utilized mineral contents of the hay. The increased ash content observed at 12 weeks suggests that the reduced microbial population during this period had favoured the ash content due to less utilization of the minerals as a result of decline in microbial activities. The highest ash content observed in conventional drying method at 6 weeks is an indication that this drying method support retention of mineral contents of the dried forage materials. This might be attributed to low utilization of mineral contents of conventional dried hay due to less microbial activities in it. With respect to non-fibrous carbohydrate (NFC) and ether extra (EE) values of the hays, EE was decreased as the storage period progresses, in contrast NFC was increased as the storage period advance. The increase in NFC observed as the storage period progressed, is an indication that soluble carbohydrates of the stored hay was improved. This might be attributed to breakdown of structural carbohydrates as a result of microbial activities during storage period. This possibly suggests that microbes that aid degradation of structural carbohydrates might be present in the hay during storage and consequently reduced fibre contents. This is in accordance with the report by Wittenberg (1997) stated that possibly new soluble carbohydrates generated from microbial breakdown of structural carbohydrates occurs as the plant soluble carbohydrates are used up by the microbes acting on them. The higher EE and the lower NFC values recorded in the solar dried hay indicates that NFC values and EE values seems to have negative relationship. This could be attributed to high utilization of the fat contents of the hay by microorganisms likewise during storage period. The higher neutral detergent fibre (NDF) and acid detergent fibre (ADL) were observed in the hay produced by solar and conventional drying techniques respectively. This shows that, as the NDF content of the hay decreases when the storage period advanced, the ADL was increasing. This could be related to breakdown of structural components of the hay due to microbial activities during storage. The observation in the present study probably suggests that solar drying method produced good hay when compared with other techniques of drying used in this study, since it is the method that produced hay having the lowest ADL content with moderate NDF content. This result is at variance with Philipp and Jennings (2015) who observed that during storage, Alfalfa hay continues to lose non-structural carbohydrates to microbial respiration, thus increasing fibre components. This could be related to occurrence of spontaneous heating which increase the internal temperature of the storage place or unfavourable environmental factors such as high temperature, low relative humidity etc. during storage period thereby reducing the population of non thermophilous micro organisms (Ewetola, 2018). However, the decline in the NDF values throughout the sampling period is an indication that the resistant microbes continually degrade the structural carbohydrates for production of energy (ATP) require for their survival.

\section{Conclusions}

Solar drying technique produced best hay having the highest $\mathrm{CP}$ content throughout the sampling periods, although the $\mathrm{CP}$ content was decreased as the storage progresses, but it still retained the $\mathrm{CP}$ content beyond the recommended rate for optimum animal performance. At 6 and 12 weeks after storage, the solar dried hay from poultry manure fertilized- Andropogon tectorum had the highest $\mathrm{CP}$ content. 


\section{Ewetola, Adebayo, Amisu, Jimoh, Dele, Olanite and Arigbede}

The NDF content of the hay was decreased while ADL was increased as storage advances.

\section{References}

Andrew, M. A., Swidiq, M., Samuel, O. Keneth, L., Fred, K., George, L. 2014. Prioritization of AgroIndustrial for Improved Productivity on smallholder dairy farms in the Lake Victoria Crescent, Uganda, Frontiers in Science, Vol. 4 No. 1, p p 1- 7 . d o i : 10.5923/j.fs.20140401.01.

A.O.A.C. 2000. Official techniques of analysis. 17th ed. Assoc. Offical Analytical Chemists. Gaithersburg, MD.

Coblentz, W. K., Jennings, J. A. and Coffey, K. P. 2008. Biology and Effects of Spontaneous Heating in hay. A published article by University of Arkansas, Division of Agricutlture, Cooperative extension Service, Animal Science Section, 2301 south University Avenue, Little Rock, page 1-8.

Ewetola, I. A. 2018. Evaluation of growth, yield and nutritive quality of fertilized Panicum maximum and Andropogon tectorum and their hay produced through different drying techniques. Ph.D Thesis Submitted to Department of Pasture and Range Management, College of Animal and Livestock Production, Federal University of Agriculture, Abeokuta, Nigeria. Pp 177.

Guerrero, J. N. 2006. Protecting hay quality during storage In: Proceedings, Western Alfalfa and forage conference. UC Cooperative Extension, Agronomy Research and Extension Center, Plant Sciences Department, University of California, Davis 95616. Pp 1-7.

Kaitho, R. J. 1997. Nutritive value of browses as protein supplement to poor quality roughages, $\mathrm{Ph}$. D thesis Wageningen Agriculture University. Pp 20.

Lamidi, A. A. and Ologbose, F. I. 2014. Dry season feeds and feeding: A treat to sustainable ruminant animal production in Nigeria. Journal of agriculture and Social Research, Vol. 14, pp. 18-31.

Mamine, F., Boumali, N.E., Montaigne, E., Arbouche, F. 2020. Why Farmers adopt Agro-Industrial ByProducts in Animal Feed? Lesson Learned in Algerian case. Annals of Social Sciences and Management studies, Volume 5 Issue $4 \mathrm{pp}$. $\begin{array}{lllllllllllll}0 & 0 & 1 & 0 & 7 & - & 0 & 0 & 1 & 1 & 3\end{array}$. DOI:10.19080/ASM.2020.05.5556 74.

Nascimento, J. M., Costa, C., Silveira, A. C. 2000. Influência do método de fenação e tempo de armazenamento sobre a composição bromatológica e ocorrência de fungos no feno de alfafa (Medicago sativa, L. cv. Flórida 77). Revista Brasileira de Zootecnia 29 (3): 669-677.

Philipp, D. and Jennings, A. J. 2015. Management of hay production, Division of Agriculture, Research and Extension, University of Arkansas system. Pp1-24.

Resch, R., Adler, A. and Potsch, E. M. 2014. Impact of different drying techniques on hay quality. Forage Conservation. Page 27-38.

Sindhu, A. A., Khan, M. A., Nisa, M. and Sarwar, M. 2002. Review AgroIndustrial By-Products as a Potential Source of Livestock Feed. International Journal of Agriculture and Biology, 1560-8530/2002/04-2307-310.http://www.ijab.org.

Van Soest, P. J, Robertson, J. B and Lewis B. A. 1991. Techniques for dietary fiber, neutral detergent fiber, and non starch polysaccharides in re- 


\section{Ewetola, Adebayo, Amisu, Jimoh, Dele, Olanite and Arigbede}

flection to animal production. Journal Dairy Science 74:35833597.

Wilkinson, J. M. 2016. Fifty years progress in forage conservation and challenges for the future. School of Biosciences, University of Nottingham, Sutton Bonington Campus, Loughborough, Leicestershire, LE12 5RD, United $\begin{array}{llllllll}K & i & n & g & d & o & m\end{array}$. j.mike.wilkinson@gmail.com
Wittenberg, K. M. 1997. Microbial and nutritive changes in forage during harvest and storage as hay. Session 14-Post-Harvest Management. Department of Animal Science, University of Manitoba, Winnipeg, Manitoba, Canada. R3T 2N2. Pp265-270.

Received: $6^{\text {th }}$ October, 2020

Accepted: $5^{\text {th }}$ February, 2021 